\title{
(2) \\ Ethnobotany of Wild and Semi-Wild Edible Fruit Species used by Maale and Ari Ethnic Communities in Southern Ethiopia
}

\author{
Berhane Kidane, L.J.G. van der Maesen, Tinde van \\ Andel, Zemede Asfaw, and M.S.M. Sosef
}

\section{Research}

\begin{abstract}
Wild and semi-wild tree fruit species are important resources in combating food insecurity and providing supplementary diet to rural people. We studied wild and semiwild fruit species used by the Maale and Ari communities in southern Ethiopia and the conservation status of these resources. We used focus group discussions $(n=18)$ and individual interviews $(n=144)$ in three rural kebeles. In total, the two communities used 52 species of wild and semi-wild fruit species which were especially important for their diet in times of food shortage. The most important species were, for the Maale community, Balanites rotundifolia (Tiegh.) Blatt. and Dobera glabra (Forssk.) Juss. ex Poir. and, for the Ari community, Carissa spinarum L. and Vitex doniana Sweet. No significant variation in ethnobotanical knowledge regarding fruit species existed among gender and age groups. The main traded fruit species were $B$. rotundifolia, Ximenia caffra Sond., and Vangueria madagascariensis J.F.Gmel. The major threats reported by informants to the availability of wild and semiwild fruit species were tree felling and conversion of forest to agricultural land. In addition to preserving the local knowledge and implementing conservation strategies that protect the remaining fruit trees, maintenance and enrichment planting of the most important species are plausible management interventions.
\end{abstract}

\section{Introduction}

Ethiopia is an ecologically diverse country that not only harbors an exceptionally rich botanical diversity (Friis et al. 2005), but is also known for its extraordinary agrobiodiversity resulting from its varied geography, climate, ethnic diversity, and strong food culture (Edwards 1991, Kahsay 2004, Wiersinga \& de Jager 2009). In Ethiopia, a large number of fruiting species are used for human con- sumption, and most come under the broad category of wild or semi-wild edible plants (Asfaw \& Tadesse 2001). Edible fruit species refer to a subset of this broad category to pinpoint the plants in which the fleshy parts of the fruit (and sometimes seeds) are eaten raw, boiled, or roasted. There have been several attempts to define the term "wild" (e.g., FAO 1999, Mengistu 2008). The term "wild" in this paper, however, refers to indigenous plants that are growing only in natural environments, while "semi-wild" applies to those plants that are indigenous or introduced and naturalized to the region while nurtured also through encouragement or tolerance by people in their crop fields, home gardens, or borders.

Millions of rural people in developing countries, including Ethiopia, are unable to obtain or produce enough food through currently conventional means. Thus, they often depend on wild and semi-wild fruit to complement and enrich their diet, especially in periods of food shortage (Akin-

\section{Correspondence}

Berhane Kidane, Ethiopian Institute of Agricultural Research, Forestry Research Center, P.O. Box 58532, Addis Ababa, ETHIOPIA.

M.S.M. Sosef, Biosystematics Group, Wageningen University and Research Center, P.O. Box 647, 6700 AP Wageningen, NETHERLANDS and Botanic Garden Meise, Nieuwelaan 38, 1860 Meise, BELGIUM.

L.J.G. van der Maesen, Tinde van Andel, Naturalis Biodiversity Center, Leiden University, P.O. Box 9517, 2300 RA Leiden, NETHERLANDS.

Zemede Asfaw, Department of Plant Biology and Biodiversity Management, The National Herbarium, Addis Ababa University, P.O. Box 3434, Addis Ababa, ETHIOPIA.

Ethnobotany Research \& Applications 12:455-471 (2014)

Published: 26 September 2014 
nifesi 2006, Balemie \& Kebebew 2006, Campbell 1987, CTA 2007, Effiong \& Udo 2010). These fruit species play a crucial role in combating food insecurity, especially the socalled "hidden hunger" caused by deficiencies of micronutrients, vitamins, and minerals (Deshmukh \& Waghmode 2011, Motlhanka \& Makhabu 2011). They also serve as a safety net for filling the gaps when cultivated fruit are scarce (CTA 2007, Valvi \& Rathod 2011).

Wild and semi-wild fruit species are not only consumed directly, but also serve to make beverages (Falconer \& Arnold 1991) or are used for other specific purposes, such as to detoxify poisonous yams (Dioscorea spp.) during cooking in the case of tamarind pods in Ghana (CTA 2007). Furthermore, by collecting and marketing them, fruit provide an additional source of income, especially for rural women and children (Effiong \& Udo 2010, Kalaba et al. 2009). Although in sub-Saharan Africa the benefits of wild and semi-wild fruit species are acknowledged by rural communities, their importance remains understudied and undervalued by outsiders (CTA 2007). Some of these edible fruit resources, however, may also have harmful effects if consumed in large amounts (Samson 2003). Thus, understanding which wild fruit species have adverse health effects will help to design future research on anti-nutritional factors and to devise solutions for possible consequences of long term consumption (Mengistu \& Hager 2009).

Wild and semi-wild fruit resources are not only important as food but may also have several other functions and services (Motlhanka et al. 2008, Tabuti et al. 2004), such as medicinal applications or bee forage, although their relative importance depends on local circumstances. Due to their diverse functions, these resources may be exposed to overexploitation or otherwise threatened, especially in periods of food scarcity. These threatening factors may vary from region to region, depending up on the local socio-economic and ecological circumstances.

Thapa (2005) stressed the important role of women in natural resource utilization and suggested that any study on natural resource utilization should begin with a gender analysis for the purpose of maintaining and improving the resource's management. Moreover, Idowu et al. (2012) highlighted the importance of gender studies for a sound conservation policy analysis and for designing effective development options. Ethiopia is sometimes called a museum of diverse ethnic communities (Yintiso 1995) as it is home to about 70 ethnic communities. Although many of these communities regularly consume wild and semi-wild fruit and consider them part of their diet, little research has been undertaken on this valuable resource (Addis 2009, Balemie \& Kebebew 2006, Mengistu \& Hager 2008). A recent review by Lulekal et al. (2011) indicated that only a small number of communities were addressed and most studies poorly dealt with issues surrounding the different gender and age groups (Balemie \& Kebebew 2006). Infor- mation on seasonal fruit availability in different parts of the country is largely lacking (Feyssa et al. 2011). To fill part of this knowledge gap, we present evidence on wild and semi-wild fruit consumption by two ethnic communities (Maale and Ari) for whom no previous information exists.

The objectives of this study are to describe and analyze the consumption, preference, and marketing of wild and semi-wild edible fruit in Maale and Ari communities. We expect that wild and semi-wild fruit species play an important role in the local diet and contribute to the nutrient intake of Maale and Ari people. Our null hypothesis is that all gender and age groups have a similar knowledge and familiarity of wild and semi-wild fruits. If differences exist in traditional knowledge among these groups, this will have an impact on the long-term availability of this food source, which should be addressed separately in any conservation strategy.

To test our hypothesis, we need to answer the following major research questions: 1) Which wild and semi-wild edible fruit species are harvested by Maale and Ari communities, in which quantities, and what is their seasonal availability? 2) Are there differences in familiarity, preference, and trade of these fruit species among age and gender groups? 3) Which criteria are important to farmers for the possible transition of wild fruit to semi-wild or even cultivated conditions? 4) Which elements affect wild and semi-wild fruit availability and trade?

\section{Materials and Methods}

\section{Study area}

The study was conducted in two communities (Maale and Ari) in the Maale and Debub Ari districts of southern Ethiopia, some $750 \mathrm{~km}$ from the capital Addis Ababa (Figure 1).

Among the other nine regions and two city administrations in the country, the Southern Nations, Nationalities and People's Regional State (SNNPR) comprises the highest number of ethnic communities (ca. 55), among which are the Maale and Ari. The language of the Maale people is called Malló mucci (Amha 2001), while the Ari speak the Araf language (Kebede 2009, Yintiso 1995).

\section{Field work}

We used combined reconnaissance surveys, field observations, discussions with individual farmers and focus groups, semi-structured key informant interviews, and preference ranking comparisons as described by Martin (1995), Alexiades (1996), and Cotton (1996). In ranking exercises, usually the highest value is given for the most preferred species and the lowest value is given for the least preferred ones. However, as this was difficult for our informants, we modified the procedure and used rank one 


\section{by Maale and Ari Ethnic Communities in Southern Ethiopia}

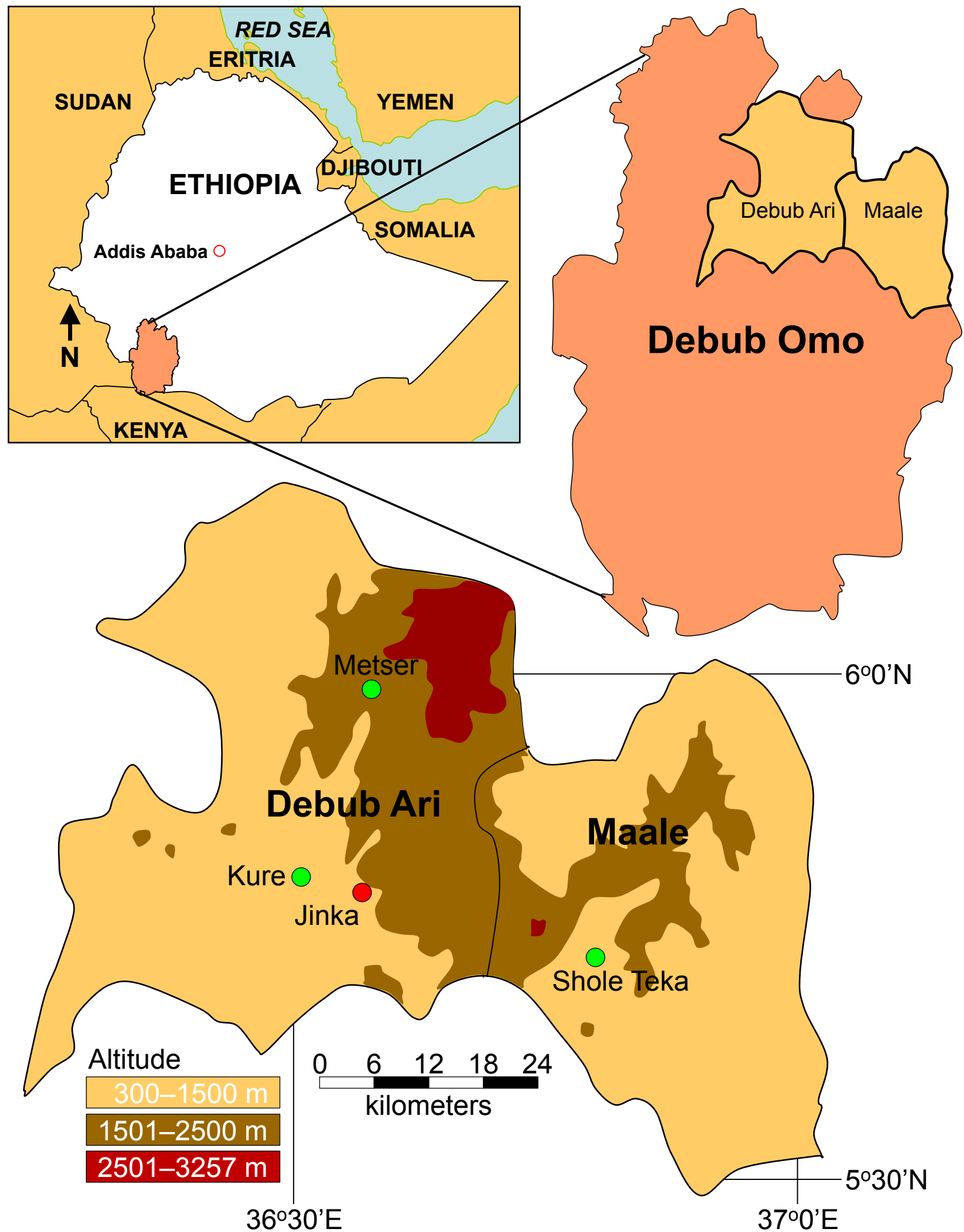

Figure 1. Study site kebeles (Kure, Metser, and Shole Teka) in Debub Ari and Maale, Debub Omo Zone, Ethiopia. 
for the most preferred ones and higher values (six or seven) for less preferred items to enable respondents to express their preference more easily.

Reconnaissance surveys were conducted in July and August 2010 in the two districts. They encompassed transect drives, walks, and discussions with administrative officials from the zone, district, and kebeles (the lowest formal administrative unit in rural Ethiopia) in the two districts. Field observations were made in the same period during village walks with key informants and local community members. Individual formal and informal discussions were carried out to compile lists of wild and semi-wild fruit species and to understand their general importance. Focus group discussions ( $n=18$ ) were also carried out. At each study site about 10-12 informants from different socio-demographic groups were involved in the focus group discussions.

Generally, a stratified simple random sampling procedure was used in selection of study sites and study participants (Alexiades 1996). Based on altitude and ethnicity, the study areas were divided into three strata. Finally, three study kebeles (one from each stratum) were randomly selected for a more detailed, formal survey. Two kebeles (Kure and Metser) were selected in Debub Ari district, which represent the midland (1500-2500 masl) and lowland (500-1500 masl) climatic zones respectively. One kebele (Shole Teka) was selected from the Maale district, which is located in the lowland climatic zone. The respective kebele offices supplied us with lists of households and household members of the study areas from which males and females were randomly selected. We used two age groups because in both communities an individual above forty was considered matured adult. Similar groupings were used by Mengistu \& Hager (2008) in their study in northern Ethiopia.

Voucher specimens were collected for wild and semi-wild fruit species used by the two ethnic communities in the presence of study participants and key informants. Preliminary identification was carried out in the field. Further, specimens were identified using taxonomic keys and floras (Edwards et al. 1997, Edwards et al. 2000, Edwards et al. 1995, Hedberg \& Edwards 1989, Hedberg et al. 2003, Hedberg et al. 2006) and compared with earlier identified specimens. Finally the specimens were deposited at the National Herbarium (ETH) of Addis Ababa University. Plant names were also checked for accuracy by means of The Plant List (www.theplantlist.org).

Market surveys were carried out from February 2011 up to February 2012 at Beneta market in the Maale area and Jinka market for Debub Ari. Markets were visited every fifteen days. All wild and semi-wild edible fruit species that were sold at these two markets were documented with their price, source, and additional trade information.

\section{Data analysis}

Data were analysed with the statistical program SPSS 16.0 (SPSS 2007). Descriptive statistics were used to illustrate averages, percentages, and market survey results. Similarities and differences in fruit consumption between sites and ethnic communities were compared by means of the Jaccard similarity index (Höft et al. 1999). This index uses positive reply (plant used as edible fruit) and negative reply (plant not used) data sets and is expressed as:

$$
\mathrm{JI}=\mathrm{c} /(\mathrm{a}+\mathrm{b}+\mathrm{c})
$$

Where $\mathrm{Jl}$ is the Jaccard similarity index, $\mathrm{c}$ is the number of species used by the two sites, a is the number of species used by the community in site $A$ only, and $b$ is the number of species by the community in site B only ( $\mathrm{Höft}$ et al. 1999).

We used a familiarity index $(\mathrm{FI})$ as a relative indicator of the popularity of the wild and semi-wild fruits within the communities (Tabuti et al. 2004), which was computed using:

$\mathrm{FI}=$ Frequency of a given species mentioned as food / Total number of respondents

The total figure of use value (UV) and the cultural importance index is the same, although defined in different ways (Tardío \& Pardo-De-Santayana 2008). We considered the use value applied by Albuquerque et al. (2006) and Rossato et al. (1999), modified from Phillips and Gentry (1993), to estimate the total cultural significance of each species. Use value was calculated using:

$$
\mathrm{UV}=\sum \mathrm{Ui} / \mathrm{n}
$$

Species use values (UV) were obtained by adding the number of uses mentioned by each informant for a given species (Ui) and dividing them by the number of informants in the survey $(n)$. The value for each specific use category was also considered and obtained by adding the number of informants mentioning a given species for a specific use and dividing this by the total number of informants (Tardío \& Pardo-De-Santayana 2008).

One-way analysis of variance (ANOVA) was performed to compare responses among different age and gender groups with regard to the familiarity and numbers of wild and semi-wild edible fruit species listed.

\section{Results}

\section{Informants}

The field study was carried out by multiple trips to the study sites from July 2010-November 2012. We random- 


\section{Kidane et al. - Ethnobotany of Wild and Semi-Wild Edible Fruit Species used by Maale and Ari Ethnic Communities in Southern Ethiopia}

Table 1. Site and socio-demographic characteristics of the participants in the formal surveys in three study site kebeles in Debub Ari and Maale, Debub Omo Zone, Ethiopia.

\begin{tabular}{|c|c|c|c|c|c|}
\hline \multirow{2}{*}{$\begin{array}{l}\text { Characteristics } \\
\text { Study sites }\end{array}$} & \multicolumn{5}{|c|}{ Site characteristics and number of individuals } \\
\hline & Shole Teka & Kure & Metser & Total & $(\%)$ \\
\hline District & Maale & Debub Ari & Debub Ari & & \\
\hline Ethnicity & Maale & Ari & Ari & & \\
\hline Vegetation & $\begin{array}{l}\text { Acacia-Commiphora } \\
\text { and Combretum - } \\
\text { Terminanlia woodland }\end{array}$ & $\begin{array}{l}\text { Moist evergreen } \\
\text { Afromontane forest } \\
\text { and Combretum - } \\
\text { Terminalia woodland }\end{array}$ & $\begin{array}{l}\text { Forest converted } \\
\text { to agricultural land; } \\
\text { scattered trees in fields } \\
\text { and home gardens }\end{array}$ & & \\
\hline Rainfall & Bimodal & Bimodal & Bimodal & & \\
\hline Male & 24 & 24 & 24 & 72 & 50 \\
\hline Female & 24 & 24 & 24 & 72 & 50 \\
\hline$<40$ years old & 24 & 24 & 24 & 72 & 50 \\
\hline$>40$ years old & 24 & 24 & 24 & 72 & 50 \\
\hline \multicolumn{6}{|l|}{ Educational status } \\
\hline Illiterate & 36 & 32 & 20 & 88 & 61 \\
\hline Read and write & 1 & 2 & 7 & 10 & 6.9 \\
\hline Grade 1-6 & 9 & 6 & 9 & 24 & 17 \\
\hline Grade 7-8 & 2 & 5 & 5 & 12 & 8.3 \\
\hline Grade 9-12 & 0 & 3 & 7 & 10 & 6.9 \\
\hline
\end{tabular}

ly selected a total of 144 individuals ( 72 male, 72 female) from households in three kebeles. Socio-demographic characteristics of the participants are listed in Table 1.

\section{Diversity of wild and semi-wild fruits used}

A total of 52 wild and semi-wild fruit-bearing species from 37 genera and 22 families were recorded among Maale and Ari communities (Appendix 1). The family Moraceae was most important (8 species), followed by the Rubiaceae (6 spp.), Fabaceae and Malvaceae (4 spp. each), and Anacardiaceae (3 spp.). Ten wild and semi-wild edible fruit species were common to both ethnic communities, while 36 species were used exclusively by the Maale and six species were consumed only by the Ari. The Jaccard's similarity indices for fruit use among the two study sites are given in Table 2. The two Ari kebeles (Kure, Metser) were more similar to each other than to the Maale kebele
Table 2. Similarity in wild and semi-wild fruit knowledge among the three study sites in Debub Ari and Maale, Debub Omo Zone, Ethiopia. * Jl values ranges from 0-1; higher values indicate a greater similarity.

\begin{tabular}{|l|c|c|}
\hline \multirow{2}{*}{$\begin{array}{l}\text { Study site } \\
\text { (ethnic group) }\end{array}$} & \multicolumn{2}{|c|}{ Jaccard Index* } \\
\cline { 2 - 3 } & $\begin{array}{c}\text { Shole Teka } \\
\text { (Maale) }\end{array}$ & $\begin{array}{c}\text { Kure } \\
\text { (Ari) }\end{array}$ \\
\hline Kure (Ari) & 0.1923 & - \\
\hline Metser (Ari) & 0.0588 & 0.5000 \\
\hline
\end{tabular}

(Shole Teka), which could be attributed to geographical proximity and shared cultural preferences for fruit species. In all three study sites, knowledge on wild and semi-wild fruits was primarily acquired or transferred from parents, followed by friends, neighbors, and accidentally encountered individuals (Table 3 ).

Table 3. Knowledge transfer means and ranking in Debub Ari and Maale, Debub Omo Zone, Ethiopia.

\begin{tabular}{|c|c|c|c|c|c|c|c|c|}
\hline \multirow{2}{*}{$\begin{array}{l}\text { Transfer } \\
\text { means } \\
\text { (source) }\end{array}$} & \multicolumn{3}{|c|}{ Sum of ranking per study site } & \multicolumn{3}{|c|}{ Mean rank } & \multirow{2}{*}{$\begin{array}{r}\text { Mean ranks } \\
\text { sum for all } \\
\text { study sites }\end{array}$} & \multirow{2}{*}{$\begin{array}{r}\text { Overall } \\
\text { rank }\end{array}$} \\
\hline & Shole Teka & Kure & Metser & Shole Teka & Kure & Metser & & \\
\hline Parents & 53 & 48 & 49 & 1.1 & 1.0 & 1.0 & 3.1 & 1 \\
\hline Friends & 103 & 117 & 130 & 2.2 & 2.4 & 2.7 & 7.3 & 2 \\
\hline Neighbors & 133 & 123 & 112 & 2.8 & 2.6 & 2.3 & 7.7 & 3 \\
\hline Accidental & 191 & 192 & 189 & 4.0 & 4.0 & 3.9 & 12 & 4 \\
\hline
\end{tabular}


The average numbers of wild and semi-wild fruit species listed by different age and gender groups and the result of the one-way ANOVA test are summarized in Table 4. The ANOVA results showed no significant difference in knowledge among different age and gender groups as all $P$ values were greater than 0.05 .

The results of familiarity index for preferred species based on taste at each site are shown in Table 5. Balanites rotun- difolia (Tiegh.) Blatt., Vitex doniana Sweet, and Garcinia livingstonei T.Anderson were the most familiar species in Shole Teka, Kure, and Metser study sites, respectively. Our ANOVA test showed no significant differences in familiarity among the gender and age groups for all sites at $P>0.05(P=0.953$ in Shole Teka, $P=0.895$ in Kure, and $P=0.847$ in Metser).

Table 4. Average number of fruit species listed by males and females in study sites in Debub Ari and Maale, Debub Omo Zone, Ethiopia.

\begin{tabular}{|lr|c|c|c|c|c|c|}
\hline \multirow{2}{*}{} & \multicolumn{4}{|c|}{ Study sites } \\
\cline { 2 - 8 } & Age & Male & Female & Male & Female & Male & Female \\
\hline & $>40$ & 11.67 & 11.42 & 4.08 & 3.50 & 2.17 & 2.25 \\
\hline & $<40$ & 12.75 & 12.17 & 3.17 & 3.42 & 2.08 & 2.83 \\
\hline ANOVAs $(P$-value) for gender \& age groups for each site & \multicolumn{2}{|c|}{0.524} & \multicolumn{3}{|c|}{0.506} & 0.635 \\
\hline ANOVA $(P$-value) for gender \& age groups in all sites & \multicolumn{4}{|c|}{0.991} \\
\hline
\end{tabular}

Table 5. Selected wild and semi-wild fruit species and their familiarity indices (in \%-age) in Shole Teka, Kure, and Metser study sites in Debub Ari and Maale, Debub Omo Zone, Ethiopia. $n=48$ in each site.

\begin{tabular}{|c|c|c|c|c|c|c|c|c|c|c|c|c|}
\hline \multirow{4}{*}{$\begin{aligned} & \text { Fruit species } \\
& \text { Age }\end{aligned}$} & \multicolumn{12}{|c|}{$\%$ in each study site } \\
\hline & \multicolumn{4}{|c|}{ Shole Teka } & \multicolumn{4}{|c|}{ Kure } & \multicolumn{4}{|c|}{ Metser } \\
\hline & \multicolumn{2}{|c|}{ Male } & \multicolumn{2}{|c|}{ Female } & \multicolumn{2}{|c|}{ Male } & \multicolumn{2}{|c|}{ Female } & \multicolumn{2}{|c|}{ Male } & \multicolumn{2}{|c|}{ Female } \\
\hline & $>40$ & $<40$ & $>40$ & $<40$ & $>40$ & $<40$ & $>40$ & $<40$ & $>40$ & $<40$ & $>40$ & $<40$ \\
\hline Balanites rotundifolia (Tiegh.) Blatt. & 67 & 83 & 92 & 92 & & & & & & & & \\
\hline $\begin{array}{l}\text { Diospyros mespiliformis Hochst. } \\
\text { ex A.DC. }\end{array}$ & 67 & 67 & 58 & 92 & & & & & & & & \\
\hline Uvaria leptocladon Oliv. & 42 & 50 & 50 & 75 & & & & & & & & \\
\hline $\begin{array}{l}\text { Bullockia pseudosetiflora (Bridson) } \\
\text { Razafim., Lantz \& B.Bremer }\end{array}$ & 50 & 25 & 50 & 58 & & & & & & & & \\
\hline Carissa spinarum L. & 75 & 8.3 & 50 & 50 & & & & & 33 & 25 & 83 & 50 \\
\hline $\begin{array}{l}\text { Meyna tetraphylla (Schweinf. } \\
\text { ex Hiern) Robyns }\end{array}$ & 42 & 25 & 42 & 67 & & & & & & & & \\
\hline Flacourtia indica (Burm.f.) Merr. & 58 & 42 & 25 & 25 & & & & & & & & \\
\hline Vitex doniana Sweet & 33 & 33 & 42 & 33 & 67 & 100 & 92 & 92 & & & & \\
\hline Grewia schweinfurthii Burret & 25 & 42 & 33 & 25 & & & & & & & & \\
\hline Vangueria madagascariensis J.F.Gmel. & 0 & 0 & 33 & 0 & & & & & & & & \\
\hline Ximenia americana $\mathrm{L}$. & & & & & 67 & 42 & 75 & 50 & & & & \\
\hline Garcinia livingstonei T.Anderson & & & & & 75 & 17 & 50 & 58 & 58 & 67 & 83 & 83 \\
\hline Manilkara butugi Chiov. & & & & & 67 & 25 & 25 & 50 & 58 & 67 & 83 & 75 \\
\hline Ficus vasta Forssk. & & & & & 33 & 25 & 25 & 33 & & & & \\
\hline Ficus sycomorus L. & & & & & 17 & 17 & 42 & 25 & & & & \\
\hline Rubus steudneri Schweinf. & & & & & 25 & 17 & 8.3 & 17 & 50 & 42 & 50 & 67 \\
\hline Syzygium guineense (Willd.) DC. & & & & & 25 & 25 & 17 & 0 & & & & \\
\hline Rubus apetalus Poir. & & & & & & & & & 17 & 8.3 & 0 & 8.3 \\
\hline
\end{tabular}




\section{Kidane et al. - Ethnobotany of Wild and Semi-Wild Edible Fruit Species used by Maale and Ari Ethnic Communities in Southern Ethiopia}

\section{Seasonal fruit availability}

Wild and semi-wild fruit species appear to be important food resources in the dry season and at the beginning of the rainy season, when there is a shortage in cultivated food in the study areas. The critical food scarcity starts in February and extends up to April or May. Food is generally in short supply during the dry period and at the beginning of the rainy season, but shortages can also occur throughout the year if there was no crop harvest in the preceding seasons. The most commonly cited fruit harvested during food shortage periods were $B$. rotundifolia and Dobera glabra (Forssk.) Juss. ex Poir. in Shole Teka, Carissa spinarum L., V. doniana, and Ximenia americana L. in Kure, and Manilkara butugi Chiov. and G. livingstonei in Metser (Table 6).

The seasonal availability of selected fruit-bearing species, especially those that are important during food shortage periods is indicated in Table 7 . Wild and semi-wild fruit species are not only important to fill the stomach during different seasons, but they also contribute essential nutrients to the local diet. Mengistu and Hager (2009) studied the nutrient contents of Ziziphus spina-christi (L.) Desf. and Diospyros mespiliformis Hochst. ex A.DC. and showed that these wild species contained higher quanti- ties of important nutrients than cultivated ones. Thus, wild and semi-wild fruit can play an important role in the local nutrient intake, provided their availability is guaranteed.

During group discussions, farmers mentioned several trees that bore fruit even in periods of severe drought: $D$. mespiliformis, Tamarindus indica L., B. rotundifolia, Ximenia caffra Sond., Sterculia africana (Lour.) Fiori, Ficus sur Forssk. (Figure 2), Grewia schweinfurthii Burret, and Ficus vasta Forssk.

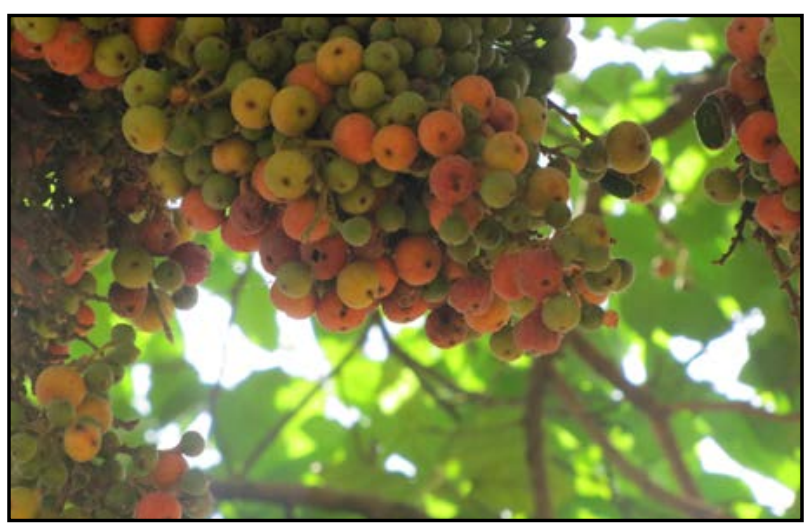

Figure 2. Ficus surForssk., an important wild fruit resource during drought periods in Debub Omo Zone, Ethiopia.

Table 6. Most important fruit species harvested during food shortage periods in Shole Teka, Kure, and Metser study sites in Debub Ari and Maale, Debub Omo Zone, Ethiopia. $n=48$ in each site.

\begin{tabular}{|l|c|c|c|}
\hline Fruit species & \multicolumn{2}{|c|}{ \% citation } \\
\hline & Shole Teka (Maale) & Kure (Ari) & Metser (Ari) \\
\hline Balanites rotundifolia (Tiegh.) Blatt. & 35.4 & & \\
\hline Dobera glabra (Forssk.) Juss. ex Poir. & 20.8 & & \\
\hline Diospyros mespiliformis Hochst. ex A.DC. & 14.6 & & \\
\hline Tamarindus indica L. & 8.3 & & \\
\hline Vangueria apiculata K.Schum. & 6.3 & & \\
\hline Uvaria leptocladon Oliv. & 6.3 & & \\
\hline Ficus vasta Forssk. & 6.3 & 8.3 & \\
\hline Ficus platyphylla Delile & 6.3 & & \\
\hline Ficus sycomorus L. & 4.2 & 8.3 & \\
\hline Vangueria madagascariensis J.F.Gmel. & 4.2 & & \\
\hline Carissa spinarum L. & & 43.8 & \\
\hline Vitex doniana Sweet & & 37.5 & \\
\hline Ximenia americana L. & & 33.3 & \\
\hline Mussaenda arcuata Poir. & & 14.6 & \\
\hline Garcinia livingstonei T.Anderson & & 14.6 & \\
\hline Manilkara butugi Chiov. & & 8.3 & \\
\hline Syzygium guineense (Willd.) DC. & & 4.2 & 12.5 \\
\hline Rubus steudneri Schweinf. & & & \\
\hline Meyna tetraphylla (Schweinf. ex Hiern) Robyns & & & \\
\hline
\end{tabular}


Table 7. Seasonal availability of selected wild and semi-wild fruit species as reported by informants in Shole Teka, Kure, and Metser in Debub Ari and Maale, Debub Omo Zone, Ethiopia. Seasons: Dry season (D), Rainy season (R).

\begin{tabular}{|c|c|c|c|c|c|c|c|c|c|c|c|c|}
\hline Months & 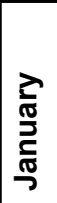 & $\begin{array}{l}\frac{\lambda}{0} \\
\frac{0}{2} \\
\frac{2}{2} \\
\frac{0}{0} \\
\stackrel{4}{4}\end{array}$ & $\frac{\frac{c}{0}}{\frac{\pi}{\pi}}$ & $\frac{\bar{c}}{\frac{2}{\alpha}}$ & $\sum_{\Sigma}^{\vec{\pi}}$ & 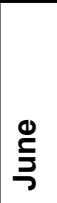 & $\frac{2}{3}$ & $\begin{array}{l}\text { 员 } \\
\frac{0}{3}\end{array}$ & 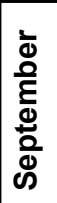 & $\begin{array}{l}\frac{亠}{ \pm} \\
\stackrel{0}{0} \\
\stackrel{0}{0} \\
0\end{array}$ & 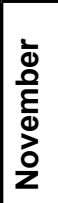 & 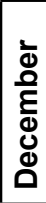 \\
\hline Season & $\mathrm{D}$ & $R$ & $\mathrm{R}$ & $\mathrm{R}$ & $\mathrm{D}$ & $\mathrm{D}$ & $R$ & $\mathrm{R}$ & $\mathrm{D}$ & $\mathrm{D}$ & D & D \\
\hline \multicolumn{13}{|l|}{ Species } \\
\hline Balanites rotundifolia (Tiegh.) Blatt. & & & $x$ & $\mathrm{X}$ & & & $x$ & $\mathrm{X}$ & & & & \\
\hline Carissa spinarum L. & & & & & & $\mathrm{X}$ & $X$ & $x$ & $X$ & & & \\
\hline Diospyros mespiliformis Hochst. ex A.DC. & $x$ & $X$ & & & & & & & & & & $x$ \\
\hline Dobera glabra (Forssk.) Juss. ex Poir. & & $\mathrm{X}$ & $\mathrm{X}$ & $\mathrm{X}$ & & & & & & & & \\
\hline Ficus platyphylla Delile & $x$ & $X$ & & & & & & & & & & $x$ \\
\hline Ficus sur Forssk. & $x$ & $\mathrm{X}$ & & & & & & & & & & $x$ \\
\hline Ficus vasta Forssk. & $x$ & $X$ & & & & & & & & & & $x$ \\
\hline Garcinia livingstonei T.Anderson & $x$ & & & & & & & & & $x$ & $x$ & $x$ \\
\hline Manilkara butugi Chiov. & & & $x$ & $\mathrm{X}$ & $\mathrm{X}$ & & & & & & & \\
\hline Mussaenda arcuata Poir. & & & $\mathrm{X}$ & $\mathrm{X}$ & & & & & & & & \\
\hline Tamarindus indica L. & $x$ & $X$ & & & & $x$ & $x$ & & & & & $x$ \\
\hline Vitex doniana Sweet & $x$ & $x$ & & & & & & & & & & \\
\hline Ximenia americana L. & & & & $\mathrm{X}$ & $X$ & & & & & & & \\
\hline
\end{tabular}

\section{Farmers' criteria and preferences} for future cultivation of fruits

Participants from both cultures distinguished seven preference criteria for the (future) cultivation of wild fruits. The most important were taste and marketability, followed by fast growth and high yield of the species (Table 8).

Maale and Ari farmers did not plant wild and semi-wild fruit trees as actively as they did with exotic domesticated fruit species, due to the better price and higher market de- mand of the latter. In Maale, $B$. rotundifolia was the only species actively grown for its fruit. Cordia africana Lam. (in Maale) and F. vasta and Ficus sycomorus L. (in Ari) were also cultivated, but mainly as shade trees in coffee plantations. Spontaneously growing fruit trees or shrubs in farms and home gardens were managed and protected to a certain extent. However, the increased demand for agricultural land made it difficult for farmers to save the remaining wild fruit species. Respondents of all three groups did not suggest enrichment planting of wild fruits in the remaining forest, but they did protect trees that al-

Table 8. Preference criteria for wild and semi-wild fruit species as reported by informants in Shole Teka, Kure, and Metser in Debub Ari and Maale, Debub Omo Zone, Ethiopia. Rank value 1 is given for the most preferred and rank value 7 given for the least preferred critera. $n=48$ in each site.

\begin{tabular}{|l|c|c|c|c|c|c|c|c|}
\hline Study sites & \multicolumn{2}{|c|}{$\begin{array}{c}\text { Shole Teka } \\
\text { (Maale) }\end{array}$} & \multicolumn{2}{|c|}{$\begin{array}{c}\text { Kure } \\
\text { (Ari) }\end{array}$} & \multicolumn{3}{|c|}{$\begin{array}{c}\text { Metser } \\
\text { (Ari) }\end{array}$} & \multicolumn{2}{c|}{ Overall } \\
\hline Criteria & $\begin{array}{c}\text { Mean } \\
\text { rank }\end{array}$ & Rank & $\begin{array}{c}\text { Mean } \\
\text { rank }\end{array}$ & Rank & $\begin{array}{c}\text { Mean } \\
\text { rank }\end{array}$ & $\begin{array}{c}\text { Rank } \\
\begin{array}{c}\text { Sum of } \\
\text { rank }\end{array}\end{array} \begin{array}{c}\text { Overall } \\
\text { rank }\end{array}$ \\
\hline Taste & 1.7 & 1 & 2.1 & 2 & 1.3 & 1 & 4 & 1 \\
\hline Marketability & 2.2 & 2 & 1.5 & 1 & 2.1 & 2 & 5 & 2 \\
\hline Fast growth and high yield & 2.8 & 3 & 3.5 & 3 & 3.0 & 3 & 9 & 3 \\
\hline Ease of collection & 5.0 & 6 & 3.8 & 4 & 4.8 & 4 & 14 & 4 \\
\hline Low shade effect on undergrowth & 4.5 & 4 & 5.3 & 5 & 5.7 & 6 & 15 & 5 \\
\hline Ease of preparation & 4.9 & 5 & 5.4 & 6 & 5.0 & 5 & 16 & 6 \\
\hline Specific cultural application & 6.6 & 7 & 6.5 & 7 & 6.1 & 7 & 21 & 7 \\
\hline
\end{tabular}




\section{Kidane et al. - Ethnobotany of Wild and Semi-Wild Edible Fruit Species used by Maale and Ari Ethnic Communities in Southern Ethiopia}

Table 9. Pair-wise mean value and rank of wild and semi-wild fruits based on taste in Shole Teka, Kure, and Metser Debub Ari and Maale, Debub Omo Zone, Ethiopia.

\begin{tabular}{|l|c|c|c|c|c|c|}
\hline Study sites & \multicolumn{2}{|c|}{ Shole Teka (Maale) } & \multicolumn{2}{c|}{ Kure (Debub Ari) } & \multicolumn{2}{l|}{ Metser (Debub Ari) } \\
\hline Species & Mean & Rank & Mean & Rank & Mean & Rank \\
\hline Balanites rotundifolia (Tiegh.) Blatt. & 7.9 & 1 & - & - & - & - \\
\hline Meyna tetraphylla (Schweinf. ex Hiern) Robyns & 5.8 & 2 & - & - & - & - \\
\hline Diospyros mespiliformis Hochst. ex A.DC. & 5.2 & 3 & - & - & - & - \\
\hline Uvaria leptocladon Oliv. & 4.7 & 4 & - & - & - & - \\
\hline $\begin{array}{l}\text { Bullockia pseudosetiflora (Bridson) Razafim., } \\
\text { Lantz \& B.Bremer }\end{array}$ & 4.2 & 5 & - & - & - & - \\
\hline Grewia schweinfurthii Burret & 4.0 & 6 & - & - & - & - \\
\hline Vangueria madagascariensis J.F.Gmel. & 3.5 & 8 & - & - & - & - \\
\hline Flacourtia indica (Burm.f.) Merr. & 3.2 & 9 & - & - & - & - \\
\hline Manilkara butugi Chiov. & - & - & 8.2 & 1 & 6.2 & 1 \\
\hline Vitex doniana Sweet & 3.8 & 7 & 6.1 & 2 & - & - \\
\hline Carissa spinarum L. & 2.8 & 10 & 5.5 & 3 & 2.9 & 5 \\
\hline Garcinia livingstonei T.Anderson & - & - & 4.9 & 4 & 4.1 & 2 \\
\hline Rubus steudneri Schweinf. & - & - & 4.7 & 5 & 3.9 & 3 \\
\hline Ximenia americana L. & - & - & 3.8 & 6 & - & - \\
\hline Ficus vasta Forssk. & - & - & 3.4 & 7 & - & - \\
\hline Syzygium guineense (Willd.) DC. & - & - & 2.1 & 8 & - & - \\
\hline Ficus sycomorus L. & - & - & 1.5 & 9 & 0.27 & 6 \\
\hline Rubus apetalus Poir. & - & - & - & - & 3.9 & 4 \\
\hline
\end{tabular}

ready grew there as these were highly appreciated. The lack of motivation for enrichment planting was associated with the problem of ownership rights, individual benefit sharing, and difficulty of close supervision. The taste preference ranking of fruit species depended on availability and knowledge based on practices. The most preferred species with regard to taste are listed in Table 9.

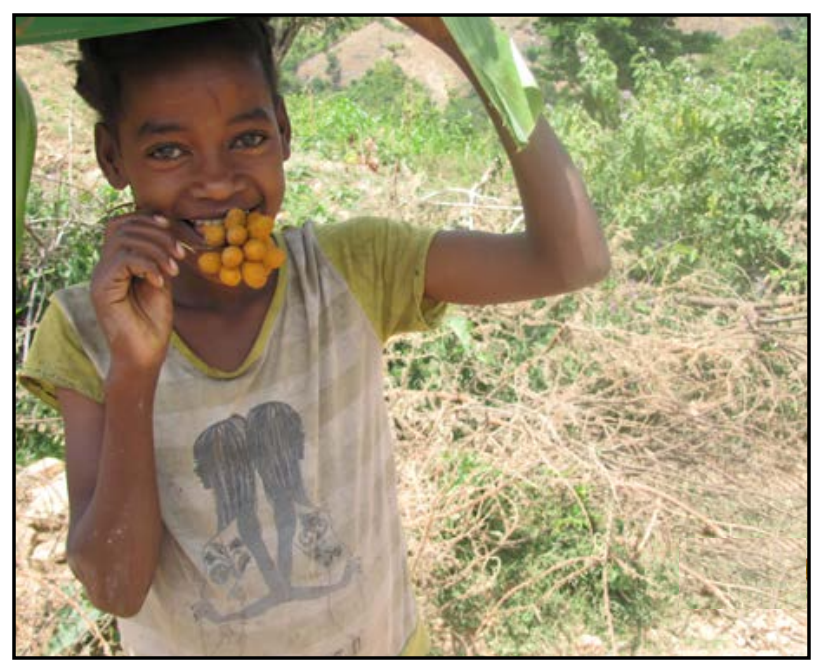

Figure 3. A young Maale girl in Shole Teka, Debub Omo Zone, Ethiopia, eating fresh Uvaria leptocladon Oliv. fruit.
Wild and semi-wild fruit harvesting and consumption

Harvesting of wild fruit was done either by shaking the plant, loosening the fruit with long sticks, or by climbing the tree. Harvesting for household consumption was usually done by all groups of people. Most fruit were consumed raw and fresh (Figure 3 ), but some were cooked with maize and sorghum flour ( $B$. rotundifolia and $D$. mespiliformis), roasted ( $S$. africana and $T$. indica), or boiled (Vangueria apiculata K.Schum. and D. glabra). Few species were processed into juice. Table 10 lists the farmer's preference of species used to prepare juice.

Table 10. Farmer's preference rank order for taste of fruit juice in Shole Teka, Maale, Debub Omo Zone, Ethiopia.

\begin{tabular}{|l|l|l|}
\hline Scientific name & $\begin{array}{l}\text { Mean } \\
\text { Rank }\end{array}$ & Rank \\
\hline Senna singueana (Delile) Lock & 1.3 & 1 \\
\hline Rhus natalensis Bernh. ex C.Krauss & 1.7 & 2 \\
\hline Rhus ruspolii Engl. & 3.3 & 3 \\
\hline Tamarindus indica L. & 3.7 & 4 \\
\hline Grewia villosa Willd. & 5.1 & 5 \\
\hline Carissa spinarum L. & 6.1 & 6 \\
\hline Bridelia micrantha (Hochst.) Baill. & 6.8 & 7 \\
\hline
\end{tabular}


Table 11. Fruit with undesirable effects and farmers' control strategy in Shole Teka, Kure, and Metser in Debub Ari and Maale, Debub Omo Zone, Ethiopia.

\begin{tabular}{|c|c|c|c|}
\hline Species & Undesirable effect & Causes & Farmers' control strategy \\
\hline $\begin{array}{l}\text { Balanites rotundifolia (Tiegh.) } \\
\text { Blatt. }\end{array}$ & \multirow[t]{4}{*}{ Diarrhea, stomach ache } & \multirow[t]{4}{*}{ Eating meat after fruit } & \multirow[t]{4}{*}{$\begin{array}{l}\text { Avoid eating meat after } \\
\text { fruit consumption }\end{array}$} \\
\hline Carissa spinarum L. & & & \\
\hline $\begin{array}{l}\text { Flacourtia indica (Burm.f.) } \\
\text { Merr. }\end{array}$ & & & \\
\hline Ximenia caffra Sond. & & & \\
\hline Cordia africana Lam. & Diarrhea, stomach ache & Excessive consumption & Drinking lime juice \\
\hline Ficus platyphylla Delile & \multirow{5}{*}{$\begin{array}{l}\text { Diarrhea, stomach ache, } \\
\text { vomiting }\end{array}$} & \multirow[t]{5}{*}{ Excessive consumption } & \multirow[t]{5}{*}{ Drinking hot coffee } \\
\hline Ficus sur Forssk. & & & \\
\hline Ficus sycomorus L. & & & \\
\hline Ficus vallis-choudae Delile & & & \\
\hline Ficus vasta Forssk. & & & \\
\hline Manilkara butugi Chiov. & $\begin{array}{l}\text { Aggravate and widen } \\
\text { wounds }\end{array}$ & $\begin{array}{l}\text { Eating the fruit or } \\
\text { drinking the juice }\end{array}$ & $\begin{array}{l}\text { Avoid drinking if one has } \\
\text { wounds }\end{array}$ \\
\hline \multirow[t]{2}{*}{ Tamarindus indica L. } & \multirow[t]{2}{*}{$\begin{array}{l}\text { Diarrhea, stomach ache, } \\
\text { vomiting }\end{array}$} & Excessive consumption & $\begin{array}{l}\text { Drinking ash mixed with } \\
\text { water }\end{array}$ \\
\hline & & Eating meat after fruit & $\begin{array}{l}\text { Drinking the decoction of } \\
\text { Rhus natalensis Bernh. } \\
\text { ex C.Krauss leaves }\end{array}$ \\
\hline
\end{tabular}

Making juice from wild fruit was not a regular practice by the Ari communities, but they occasionally did this with $X$. americana, G. livingstonei, C. spinarum, and M. butugi. Moreover, the Ari boiled unripe fruits of $C$. spinarum to prepare soup during critical periods of the year. In some cases, the Maale also stored B. rotundifolia and D. glabra seeds for later use in traditional dishes. Balanites rotundifolia seeds can be stored for a year under dry conditions. Long storability was considered as one of the important characteristics of the fruit that were used during food shortage.

\section{Side effects of wild fruit consumption and farmers' control strategies}

Knowledge of wild fruit characteristics and farmers' control strategy is crucial, not only for dietary purposes, but also to prevent or treat the side effects of overconsumption. Experiences from Maale and Ari farmers and their remedies are indicated in Table 11. Excessive consumption of certain fruit species was mentioned to cause stomach and bowel problems. The use of wood ash as a possible remedy should be studied further to understand possible health effects. Moreover, the reported side effects caused by eating meat immediately after consuming certain fruit species requires further research attention.

\section{Other uses of wild and semi-wild fruits}

Several wild and semi-wild fruit species with important cultural meaning are listed in Table 12. Balanites rotundifolia, $V$. doniana, and G. livingstonei had the highest use value or cultural significance in Shole Teka, Kure, and Metser sites, respectively.

\section{Major threats to wild and semi-wild fruits}

According to the Maale and Ari participants, agricultural expansion was the main threat to wild fruit availability (Table 13). Population pressure, combined with declining productivity of agricultural land, forced the communities to expand their fields to the remaining patches of forest, resulting in increased deforestation and a decline in wild fruit trees. The recent increased value of land contributed to further expansion to the remaining forested patches. The threats were similar in all study sites, but respondents ranked it differently. In Kure the selective harvesting for other uses was ranked as a major threat next to agricultural expansion.

\section{Trade in wild and semi-wild fruits}

Collecting wild and semi-wild fruit to sell in the market was said to be a common practice by the rural communities during different seasons. Unlike cultivated species, which were sold along road sides, marketing of wild and semi-wild fruit only took place at the main markets. The fruit were main- 


\section{Kidane et al. - Ethnobotany of Wild and Semi-Wild Edible Fruit Species used by Maale and Ari Ethnic Communities in Southern Ethiopia}

Table 12. Use value (UV) of species in Shole Teka (S), Kure (K), and Metser (M), in Debub Ari and Maale, Debub Omo Zone, Ethiopia.

\begin{tabular}{|c|c|c|c|c|c|c|c|c|c|c|c|c|}
\hline Species & 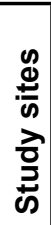 & $\begin{array}{l}\stackrel{0}{\frac{\delta}{0}} \\
\frac{0}{0} \\
\frac{0}{\Sigma}\end{array}$ & 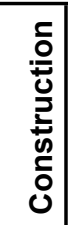 & 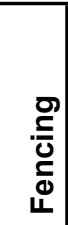 & $\begin{array}{l}\frac{0}{0} \\
\stackrel{0}{0} \\
\vdots \\
\frac{1}{4}\end{array}$ &  & $\begin{array}{l}\frac{1}{0} \\
\frac{0}{0} \\
\text { 유 }\end{array}$ & 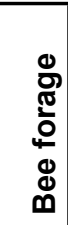 &  & 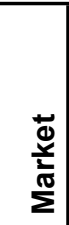 & 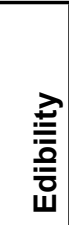 &  \\
\hline Garcinia livingstonei T.Anderson & $M$ & 0.3 & 1.0 & 1.0 & 1.0 & 1.0 & 0 & 1.0 & 1.0 & 0.9 & 1.0 & 8.2 \\
\hline Manilkara butugi Chiov. & $\mathrm{M}$ & 0 & 0.8 & 1.0 & 1.0 & 1.0 & 0 & 1.0 & 0.8 & 1.0 & 1.0 & 7.6 \\
\hline Balanites rotundifolia (Tiegh.) Blatt. & $S$ & 1.0 & 0.3 & 1.0 & 0.5 & 0.9 & 0.6 & 0.8 & 0.1 & 1.0 & 1.0 & 7.2 \\
\hline Ficus sycomorus L. & $\mathrm{M}$ & 0 & 1.0 & 1.0 & 0.6 & 1.0 & 0 & 0.4 & 0.9 & 0.4 & 1.0 & 6.3 \\
\hline Meyna tetraphylla (Schweinf. ex Hiern) Robyns & $S$ & 1.0 & 0.2 & 1.0 & 0 & 1.0 & 1.0 & 0.8 & 0 & 0 & 1.0 & 6.0 \\
\hline Diospyros mespiliformis Hochst. ex A.DC. & $S$ & 0 & 0.9 & 0.9 & 0.9 & 1.0 & 0.1 & 0.6 & 0.6 & 0 & 1.0 & 6.0 \\
\hline Vitex doniana Sweet & $\mathrm{K}$ & 0 & 0.2 & 0.8 & 0.2 & 1.0 & 0 & 0.9 & 0.8 & 0.9 & 1.0 & 5.8 \\
\hline Vitex doniana Sweet & $S$ & 0 & 0.5 & 0.5 & 0.1 & 1.0 & 0.2 & 0.7 & 0.8 & 0.2 & 1.0 & 5.0 \\
\hline Syzygium guineense (Willd.) DC. & $\mathrm{K}$ & 0 & 0.1 & 1.0 & 0.1 & 1.0 & 0 & 0.3 & 1.0 & 0.3 & 1.0 & 4.8 \\
\hline Carissa spinarum $\mathrm{L}$. & $S$ & 0.2 & 0.1 & 1.0 & 0 & 0.8 & 0.8 & 0.8 & 0 & 0 & 1.0 & 4.7 \\
\hline Manilkara butugi Chiov. & $\mathrm{K}$ & 0 & 0.6 & 0.8 & 0.3 & 1.0 & 0 & 0.3 & 0.4 & 0.2 & 1.0 & 4.6 \\
\hline Flacourtia indica (Burm.f.) Merr. & $S$ & 0 & 0.1 & 1.0 & 0.2 & 1.0 & 0.6 & 0.5 & 0.1 & 0 & 1.0 & 4.5 \\
\hline Grewia schweinfurthii Burret & $S$ & 0 & 0.1 & 0.6 & 0 & 1.0 & 0.8 & 0.8 & 0.1 & 0 & 1.0 & 4.4 \\
\hline Ficus vasta Forssk. & $\mathrm{K}$ & 0 & 0.1 & 0.8 & 0.1 & 1.0 & 0.2 & 0.1 & 0.9 & 0 & 1.0 & 4.2 \\
\hline Ficus sycomorus L. & $\mathrm{K}$ & 0 & 0 & 0.9 & 0 & 1.0 & 0.3 & 0.2 & 0.6 & 0 & 1.0 & 4.0 \\
\hline Rubus steudneri Schweinf. & $\mathrm{M}$ & 0.1 & 0 & 0.9 & 0 & 0.9 & 0.1 & 0.2 & 0 & 0.8 & 1.0 & 4.0 \\
\hline Uvaria leptocladon Oliv. & $\mathrm{S}$ & 0.1 & 0.3 & 0.8 & 0 & 0.7 & 0.1 & 0.9 & 0.1 & 0 & 1.0 & 4.0 \\
\hline Garcinia livingstonei T.Anderson & $\mathrm{K}$ & 0.1 & 0.2 & 0.9 & 0.2 & 1.0 & 0 & 0.1 & 0 & 0.3 & 1.0 & 3.8 \\
\hline Carissa spinarum L. & $\mathrm{K}$ & 0.1 & 0 & 0 & 0 & 0.9 & 0 & 0.8 & 0 & 0.8 & 1.0 & 3.6 \\
\hline Rubus apetalus Poir. & $\mathrm{M}$ & 0 & 0.2 & 0.8 & 0 & 0.8 & 0 & 0.5 & 0 & 0.2 & 1.0 & 3.5 \\
\hline Vangueria madagascariensis J.F.Gmel. & $S$ & 0 & 0 & 0.7 & 0 & 0.8 & 0 & 0.7 & 0 & 0 & 1.0 & 3.2 \\
\hline Ximenia americana L. & $\mathrm{K}$ & 0.9 & 0 & 0 & 0 & 0.9 & 0 & 0 & 0 & 0.2 & 1.0 & 3.0 \\
\hline Rubus steudneri Schweinf. & $\mathrm{K}$ & 0 & 0 & 0.2 & 0 & 1.0 & 0.1 & 0 & 0 & 0.4 & 1.0 & 2.7 \\
\hline $\begin{array}{l}\text { Bullockia pseudosetiflora (Bridson) Razafim., } \\
\text { Lantz \& B.Bremer }\end{array}$ & $S$ & 0 & 0 & 0.3 & 0 & 0.4 & 0.7 & 0.1 & 0 & 0 & 1.0 & 2.5 \\
\hline Carissa spinarum L. & $M$ & 0 & 0 & 0.5 & 0 & 0.7 & 0.1 & 0 & 0 & 0 & 1.0 & 2.3 \\
\hline
\end{tabular}

Table 13. Major threats to fruit species according to respondents $(n=144)$ in Shole Teka, Kure, and Metser, in Debub Ari and Maale, Debub Omo Zone, Ethiopia. 0 - not mentioned as a threat.

\begin{tabular}{|l|c|c|c|c|c|c|}
\hline Threats & \multicolumn{2}{|c|}{ Shole Teka } & \multicolumn{3}{|c|}{ Kure } & \multicolumn{2}{c|}{ Metser } \\
\cline { 2 - 7 } & Mean & Rank & Mean & Rank & Mean & Rank \\
\hline Agricultural land expansion & 1.6 & 1 & 2.8 & 1 & 1.5 & 1 \\
\hline Fuel wood collection & 3.3 & 3 & 3.0 & 3 & 2.7 & 2 \\
\hline Selective harvesting for construction, farm tools, etc. & 4.6 & 5 & 2.9 & 2 & 4.1 & 4 \\
\hline No enrichment planting in crop fields or home gardens & 2.8 & 2 & 4.7 & 6 & 2.9 & 3 \\
\hline Wild fire & 5.5 & 6 & 3.0 & 4 & 5.7 & 6 \\
\hline Drought/shortage of rainfall & 5.7 & 7 & 4. & 5 & 4.2 & 5 \\
\hline Grazing & 4.6 & 4 & 0 & 0 & 0 & 0 \\
\hline
\end{tabular}


ly harvested from the remaining forest patches, although farmers mentioned they were occasionally harvested from home gardens and crop fields. The main actors in the wild and semi-wild fruit market chain were farmers (collectors) and customers (buyers). The market chain was very short; no middlemen were involved. During our survey at Jinka market, we only noticed Vangueria madagascariensis J.F.Gmel for sale, but according to consumers, fruit of $M$. butugi, Syzygium guineense (Willd.) DC., V. doniana, and C. spinarum were also marketed. At Beneta market, we only saw the seeds of $B$. rotundifolia and $X$. caffra being offered for sale.

Prices of wild and semi-wild fruit species were very low compared to cultivated species such as mango (Mangifera indica L.), avocado (Persea americana Mill.), or banana (Musa acuminata $\times$ balbisiana Colla). Study results showed that on average $1 \mathrm{~kg}$ of banana was sold for ca. 4 Birr (0.2 USD), whereas $1 \mathrm{~kg}$ of $V$. madagascariensis fruit was sold for ca. 1 Birr (0.05 USD). Traders purchased cultivated fruits either from the farmers' fields or bought them at the local market and sold them again. However, we did not encounter any trader that was involved in the marketing of wild and semi-wild fruits in the area during our fieldwork. The major reasons why traders were not buying and selling wild and semi-wild fruits were the lack of supply and the low prices. Lack of fruit stalls, short shelf life, and lack of storage facilities were also mentioned by traders as the major constraints in the marketing of cultivated species. Value additions by partial processing or packaging were practices with which our informants were not familiar.

\section{Discussion}

The higher consumption of wild and semi-wild fruit species by the Maale can be explained by the presence of higher numbers of fruit trees in the local vegetation and good experiences with their use by the community. Mengistu and Hager (2008) also argued that the various Ethiopian communities may utilize different species, and species importance depends on local practices. Jin et al. (1999) reported similar observations for Yunnan (China). These authors also emphasized that the extent of wild and semiwild fruit use depended on the level of agricultural productivity and the environment.

No significant variation in the knowledge of wild and semiwild fruits was found for the different age and gender groups. This indicates an open knowledge transfer in the communities, which is important for knowledge continuity and future participatory development and conservation plans. Our results differed from those reported by Mengistu and Hager (2008), who found that Amhara youngsters were more knowledgeable on edible fruit than elders because some species that were not considered edible in earlier days were discovered as edible by a younger generation during times of (extreme) food scarcity.

The wild and semi-wild fruit species in our study sites were available throughout the seasons, including during food shortages, which indicates that they play a supplementary role during nutrition crises. In this regard, our results are in line with those of Mengistu and Hager (2009) and Pinstrup-Andersen (2009), who emphasized the importance of wild fruit in periods of food shortage to assure a healthy and nutritionally balanced diet. However, when wild fruit are consumed in low amounts, they have little influence on dietary intake and nutritional security, as Termote et al. (2012) recorded for Congo. Just as in Central Africa, the consumption of wild fruit in Ethiopia should be stimulated to increase their role in the balanced diet of rural people while giving due attention to sustainable management of resources. Feyssa et al. (2011) reported that many people in the Boosat and Fantalle districts of east Shewa, Ethiopia, survived by partly eating $D$. glabra fruit during severe hunger periods some 50 years ago. The tree requires little rain to bear fruit. Dobera glabra was also listed by the Maale as an important species during food shortage periods.

Just as in South Africa (Shackleton et al. 2000), taste was an important criterion for wild fruit preference. Such preferences, however, may vary from one study site to another (Mengistu \& Hager 2008). Preference criteria set by the communities should be taken into consideration in any research development program in order to optimize community acceptance or adoption of wild fruit species.

According to our data, the availability of fruit was mainly affected by agricultural land expansion, which is a common phenomenon in different parts of Ethiopia, such as Derashe and Kucha in southern Ethiopia (Balemie \& Kebebew 2006). Agricultural expansion affects resource availability in rural areas thereby decreasing the volume of fruit harvestable for private consumption and sale.

The low price and inadequate market supply of wild and semi-wild fruit species discouraged traders from marketing this resource and also hampered the promotion of trade. Thus, it is important to work towards the maintenance or improvement of this resource to increase its supply. Moreover, market opportunities for rural farmers and traders should be improved to increase the current revenues obtained from wild and semi-wild fruit species.

\section{Conclusions}

Rural Ethiopian communities such as the Maale and Ari consume a wide variety of wild and semi-wild fruit species. Their availability during food shortage periods makes them important dietary supplements in rural areas. Moreover, the consumption of species with a relatively high 


\section{Kidane et al. - Ethnobotany of Wild and Semi-Wild Edible Fruit Species used 467 by Maale and Ari Ethnic Communities in Southern Ethiopia}

level of essential nutrients showed their role in food security. Both communities have a broad knowledge of wild and semi-wild edible fruit species, which offers opportunities for future conservation of plant resources as it will be relatively easy to implement conservation strategies compared to communities with limited knowledge. No significant variation on wild and semi-wild edible fruit knowledge was found between gender and age groups.

Agricultural expansion was mentioned as the major threat for the survival of wild fruit species. Beside alternative conservation strategies (in- and ex-situ) to protect the remaining forests, cultivation aims at gradual domestication, hence maintenance and enrichment planting of the most preferred species such as Balanites rotundifolia, Vitex doniana, and Garcinia livingstonei is recommended. The focus should be on enrichment planting in home gardens and nearby crop fields because these are easily supervised and do not involve ownership disputes. Moreover, it is important to take away the pressure from the natural forest.

Species with a high market value, good taste, fast growth, and high yield should be considered for promotion, but species that bear fruit during food shortage periods should not be overlooked. Consideration of local farmers' preferences is crucial for development programs. Low prices and poor market and outlet opportunities hamper the trade in wild fruits. Creating demand and facilitating better market outlets will encourage communities to cultivate wild and semi-wild fruit species. For example, for fruit that are harvested in bulk, value addition by making jams, jellies, or canned juice, as is done with Opuntia ficus-indica (L.) Mill. in northern Ethiopia, could be an option.

\section{Acknowledgments}

This research project was granted by Netherlands Organization for International Cooperation in higher education (Netherlands Fellowship Programmes) as part of the PhD research of the first author. We thank Netherlands Organization for International Cooperation in higher education for funding. Our gratefulness goes to the informants in all study sites who shared with us their knowledge on wild and semi-wild edible fruits. Our appreciation goes also to staff of the National Herbarium Addis Ababa University and of the Biosystematics group at Wageningen University for their technical assistance. We are also thankful to zonal, district, and kebele administrators and experts in the study area.

\section{Literature Cited}

Addis, G. 2009. Edible Wild and Semi-Wild Plants of Hamar and Xonso (South Ethiopia) with Emphasis on Their Ethnobotany and Nutritional Composition of Select- ed Species. Ph.D. Thesis, Addis Ababa University, Addis Ababa, Ethiopia.

Akinnifesi, F.K., F. Kwesiga, J. Mhango , T. Chilanga , A. Mkonda, C.A.C. Kadu, I. Kadzere, D. Mithofer, J.D.K. Saka, G. Sileshi, T. Ramadhani \& P. Dhliwayo. 2006. Towards the development of miombo fruit trees as commercial tree crops in southern Africa. Forests, Trees and Livelihoods 16(1):103-121. dx.doi.org/10.1080/14728028.20 $\underline{06.9752548}$

Albuquerque, U.P., R.F.P. Lucena, J.M. Monteiro, A.T.N. Florentino \& C.F.C.B.R. Almeida. 2006. Evaluating two quantitative ethnobotanical techniques. Ethnobotany $R e-$ search \& Applications 4:51-60.

Alexiades, M.N. 1996. Collecting ethnobotanical data: An introduction to basic concepts and techniques. Pp. 5394 in Selected Guidelines for Ethnobotanical Research: A field manual. Edited by M.N. Alexiades. The New York Botanical Garden, Bronx, New York, U.S.A.

Amha, A. 2001. The Maale Language. Research School of Asian, African, and Amerindian Studies, Universiteit Leiden, Leiden, Netherlands.

Asfaw, Z. \& M. Tadesse. 2001. Prospects for sustainable use and development of wild food plants in Ethiopia. Economic Botany 55(1):47-62. dx.doi.org/10.1007/ BF02864545

Balemie, K. \& F. Kebebew. 2006. Ethnobotanical study of wild edible plants in Derashe and Kucha Districts, South Ethiopia. Journal of Ethnobiology and Ethnomedicine 2:53. dx.doi.org/10.1186/1746-4269-2-53

Campbe, B.M. 1987. The use of wild fruits in Zimbabwe. Economic Botany 41(3):375-385. dx.doi.org/10.1007/ BF02859054

Cotton, C.M. 1996. Ethnobotany: Principles and applications. John Wiley and Sons Ltd., West Sussex, England, U.K.

CTA (Technical Centre for Agricultural and Rural Cooperation). 2007. Indigenous Fruits. Technical information. Rural Radio Resource Pack. www.cta.int

Deshmukh, B.S. \& A. Waghmode. 2011. Role of wild edible fruits as a food resource: Traditional knowledge. International Journal of Pharmacy and Life Sciences 2(7):919924.

Edwards, S.B. 1991. Crops with wild relatives found in Ethiopia. Pp. 42-74 in Plant Genetic Resources of Ethiopia. Edited by J.M.M. Engels, J.G. Hawkes \& M. Werede. Cambridge University Press, Cambridge, U.K. 
Edwards, S.B., S. Demissew \& I. Hedberg, eds. 1997. Flora of Ethiopia and Eritrea. Hydrocharitaceae to Arecaceae, Volume 6. The National Herbarium, Addis Ababa, Ethiopia, and Department of Systematic Botany, Uppsala, Sweden.

Edwards, S.B., M. Tadesse, S. Demissew \& I. Hedberg, eds. 2000. Flora of Ethiopia and Eritrea. Magnoliaceae to Flacourtiaceae, Volume 2. Part 1. The National Herbarium, Addis Ababa, Ethiopia, and Department of Systematic Botany, Uppsala, Sweden.

Edwards, S.B., M. Tadesse \& I. Hedberg, eds. 1995. Flora of Ethiopia and Eritrea. Canellaceae to Euphorbiaceae, Volume 2, Part 2. The National Herbarium, Addis Ababa, Ethiopia, and Department of Systematic Botany, Uppsala, Sweden.

Effiong, G.S. \& I.F. Udo. 2010. Nutritive values of four indigenous wild fruits in Southeastern Nigeria. Electronic Journal of Environmental, Agricultural and Food Chemistry 9(7):1168-1176.

Falconer, J. \& J.E.M. Arnold. 1991. Household Food Security and Forestry: An analysis of socio-economic issues. Food and Agriculture Organization of the United Nations (FAO), Rome, Italy. www.fao.org/docrep/006/t6125e/ T6125E00.htm

FAO (Food and Agriculture Organization). 1999. Use and Potential of Wild Plants in Farm Households. Food and Agriculture Organization of the United Nations (FAO), Rome, Italy. www.fao.org/docrep/003/W8801E/w8801e01.htm

Feyssa, D.H., J.T. Njoka, Z. Asfaw \& M.M. Nyangito. 2011. Seasonal availability and consumption of wild edible plants in semiarid Ethiopia: Implications to food security and climate change adaptation. Journal of Horticulture and Forestry 3(5):138-149.

Friis, I., M. Thulin, H. Adsersen \& A.-M. Bürger. 2005. Patterns of plant diversity and endemism in the Horn of Africa. Pp. 289-314 in Plant Diversity and Complexity Patterns: Local, regional and global dimensions. Edited by I. Friis \& $\mathrm{H}$. Balslev. Proceedings of an International symposium held at the Royal Danish Academy of Sciences and Letters in Copenhagen, Denmark, 25-28 May 2003. Biologiske Skrifter 55:289-314.

Hedberg, I. \& S.B. Edwards, eds. 1989. Flora of Ethiopia. Pittosporaceae to Araliaceae, Volume 3. The National Herbarium, Addis Ababa, Ethiopia, and Department of Systematic Botany, Uppsala, Sweden.

Hedberg, I., S.B. Edwards \& S. Nemomissa, eds. 2003. Flora of Ethiopia and Eritrea. Apiaceae to Dipsacaceae, Volume 4, Part 1. The National Herbarium, Addis Ababa,
Ethiopia, and Department of Systematic Botany, Uppsala, Sweden.

Hedberg, I., E. Kelbesa, S.B. Edwards, S. Demissew \& E. Persson. 2006. Editors of Flora of Ethiopia and Eritrea. Gentianaceae to Cyclocheilacea, Volume 5. The National Herbarium, Addis Ababa, Ethiopia, and Department of Systematic Botany, Uppsala, Sweden.

Höft, M., S.K. Barik \& A.M. Lykke. 1999. Quantitative Ethnobotany: Applications of multivariate and statistical analyses in ethnobotany. People and Plants Working Paper 6. People and Plants Initiative, Division of Ecological Sciences, United Nations Educational, Scientific and Cultural Organization (UNESCO), Paris, France.

Kahsay, B. 2004. Land Use and Land Cover Changes in the Central Highlands of Ethiopia: The case of Yerer mountain and its surroundings. M.Sc. thesis, Addis Ababa University, Addis Ababa, Ethiopia.

Kebede, T. 2009. Changes in the Production Practices of the Ari People, South Western Ethiopia. M.A. thesis, Addis Ababa University, Addis Ababa, Ethiopia.

Lulekal, E., Z. Asfaw, E. Kelbessa \& P. Van Damme. 2011. Wild edible plants in Ethiopia: A review on their potential to combat food insecurity. Afrika Focus 24(2):71-121. www. gap.ugent.be/africafocus/pdf/2011vol24nr2_lulekal.pdf

Martin, G.J. 1995. Ethnobotany: A method manual. Chapman and Hall, London, U.K.

Mengistu, F. 2008. Fruit Tree Species in the Wild and in Home Garden Agroforestry: Species composition, diversity and utilization in Western Amhara Region, Ethiopia. Ph.D. Thesis, University of Natural Resources and Applied Life Sciences, Vienna, Austria.

Mengistu, F. \& H. Hager. 2008. Wild edible fruit species cultural domain, informant species competence and preference in three districts of Amhara Region, Ethiopia. Ethnobotany Research \& Applications 6:487-502.

Mengistu, F. \& H. Hager. 2009. Exploiting locally available resources for food and nutritional security enhancement: Wild fruits diversity, potential and state of exploitation in the Amhara region of Ethiopia. Food Security 1(2):207219. dx.doi.org/10.1007/s12571-009-0017-z

Motlhanka, D.M. \& S.W. Makhabu. 2011. Medicinal and edible wild fruit plants of Botswana as emerging new crop opportunities. Journal of Medicinal Plants Research 5(10):1836-1842.

Motlhanka, D.M.T., P. Motlhanka \& T. Selebatso. 2008. Edible indigenous wild fruit plants of Eastern Botswana. 


\section{Kidane et al. - Ethnobotany of Wild and Semi-Wild Edible Fruit Species used 469 by Maale and Ari Ethnic Communities in Southern Ethiopia}

International Journal of Poultry Science 7(5):457-460. www.pjbs.org/ijps/fin1090.pdf

Pinstrup-Andersen, P. 2009. Food security: Definition and measurement. Food Security 1:5-7. dx.doi.org/10.1007/ s12571-008-0002-y

Phillips, O. \& A.H. Gentry. 1993. The useful plants of Tambopata, Peru: II. Additional hypothesis testing in quantitative ethnobotany. Economic Botany 47(1):33-43. dx.doi. org/10.1007/BF02862204

Rossato, S.C., H.F. Leitão-Filho \& A. Begossi .1999. Ethnobotany of Caiçaras of the Atlantic Forest Coast (Brazil). Economic Botany 53(4):387-395. dx.doi.org/10.1007/ BF02866716

Samson, J.A. 2003. Tropical Fruits. Second edition. Blackwell Publishing, Oxford, England, U.K.

Shackleton, C.M., C.M. Dzerefos, S.E. Shackleton \& F.R. Mathabela. 2000. The use of and trade in indigenous edible fruits in the Bushbuckridge savannah region, South Africa. Ecology of Food and Nutrition 39(3):225-245. dx.doi. org/10.1080/03670244.2000.9991616

SPSS. 2007. Statistical Package for the Social Sciences. For Windows, Version 16.0. SPSS Inc., Chicago, Illinois, U.S.A.

Tabuti, J.R.S., S.S. Dhillion \& K.A. Lye. 2004. The status of wild food plants in Bulamogi County, Uganda. International Journal of Food Sciences and Nutrition 55(6):485498. $\mathrm{dx}$.doi.org/10.1080/09637480400015745
Tardío, J. \& M. Pardo-De-Santayana. 2008. Cultural importance indices: A comparative analysis based on the useful wild plants of southern Cantabria (northern Spain). Economic Botany 62(1):24-39. dx.doi.org/10.1007/ s12231-007-9004-5

Termote, C., M.B. Meyi, B.D. Djailo, L. Huybregts, C. Lachat, P. Kolsteren \& P. Van Damme. 2012. A biodiverse rich environment does not contribute to a better diet: $A$ case study from DR Congo. PLoS ONE 7(1):e30533. dx.doi.org/10.1371/journal.pone.0030533

Thapa, M. 2005. Natural Resource Management from Gender Perspectives. Paper presented at "When Women Gain, So Does the World," Eighth International Women's Policy Research Conference, Washington, D.C., U.S.A., 19-21 June 2005.

Valvi, S.R. \& V.S. Rathod. 2011. Mineral composition of some wild edible fruits from Kolhapur district. International Journal of Applied Biology and Pharmaceutical Technology 2(1):392-396. www.ijabpt.com/pdf/22065-IIValvi\%5B1\%5D.pdf

Wiersinga, R. \& A. de Jager. 2009. Business Opportunities in the Ethiopian Fruit and Vegetable Sector. Wageningen University and Research Centre, LEI, Wageningen, Netherlands.

Yintiso, G. 1995. The Ari of South Western Ethiopia: An exploratory study of production practices. Social Anthropology Dissertation Series No 2, Addis Ababa University, Addis Ababa, Ethiopia. 
Appendix 1. Wild and semi-wild tree fruit species in Shole Teka, Kure, and Metser kebeles, in Debub Ari and Maale, Debub Omo Zone, Ethiopia. Local languages: Malló mucci (M), Araf (A).

\begin{tabular}{|c|c|c|c|c|c|}
\hline \multicolumn{3}{|l|}{ Plant names } & \multicolumn{3}{|c|}{ Study sites } \\
\hline \multicolumn{2}{|c|}{ Scientific names } & Local names & 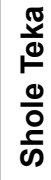 &  & 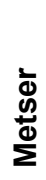 \\
\hline \multirow[t]{3}{*}{ Anacardiaceae } & Rhus natalensis Bernh. ex C.Krauss & kubri (M) & $\mathrm{X}$ & & \\
\hline & Rhus ruspolii Engl. & shawshini $(\mathrm{M})$ & $\mathrm{X}$ & & \\
\hline & Sclerocarya birrea (A.Rich.) Hochst. & tunkelo (M) & $\mathrm{X}$ & & \\
\hline \multirow[t]{2}{*}{ Annonaceae } & Annona senegalensis Pers. & dangarasho $(\mathrm{M})$ & $\mathrm{X}$ & & \\
\hline & Uvaria leptocladon Oliv. & muralatse $(\mathrm{M})$ & $\mathrm{X}$ & & \\
\hline \multirow[t]{2}{*}{ Apocynaceae } & Carissa spinarum L. & ambelto $(\mathrm{M})$, almi $(\mathrm{A})$ & $\mathrm{X}$ & $X$ & $\mathrm{X}$ \\
\hline & Saba comorensis (Bojer ex A.DC.) Pichon & kalikedo $(\mathrm{M})$ & $\mathrm{X}$ & & \\
\hline Arecaceae & Phoenix reclinata Jacq. & zembaba $(A)$ & & $X$ & $X$ \\
\hline \multirow[t]{2}{*}{ Boraginaceae } & Cordia africana Lam. & galmi (M) & $\mathrm{X}$ & & \\
\hline & Cordia sinensis Lam. & shengolochi $(\mathrm{M})$ & $\mathrm{X}$ & & \\
\hline Clusiaceae & Garcinia livingstonei T.Anderson & chedi $(A)$ & & $\mathrm{X}$ & $\mathrm{X}$ \\
\hline \multirow[t]{2}{*}{ Ebenaceae } & Diospyros mespiliformis Hochst. ex A.DC. & goroki (M) & $\mathrm{X}$ & & \\
\hline & Euclea divinorum Hiern & ounsi $(\mathrm{M})$ & $\mathrm{X}$ & & \\
\hline \multirow[t]{4}{*}{ Fabaceae } & Bauhinia thonningii Schum. & dawrake $(\mathrm{M})$, lol $(\mathrm{A})$ & $\mathrm{X}$ & $\mathrm{X}$ & \\
\hline & Senna singueana (Delile) Lock & karahaleko (M) & $\mathrm{X}$ & & \\
\hline & Tamarindus indica L. & rokee $(\mathrm{M})$ & $\mathrm{X}$ & & \\
\hline & Tylosema fassoglensis (Schweinf.) Torre \& Hillc. & dankilo (M) & $\mathrm{X}$ & & \\
\hline \multirow[t]{2}{*}{ Lamiaceae } & Hoslundia opposita Vahl & lisho $(M)$ & $\mathrm{X}$ & & \\
\hline & Vitex doniana Sweet & woro goroki $(M)$, gorka $(A)$ & $\mathrm{X}$ & $\mathrm{X}$ & \\
\hline Loganiaceae & Strychnos innocua Delile & jalijecho $(\mathrm{M})$ & $\mathrm{X}$ & & \\
\hline \multirow[t]{4}{*}{ Malvaceae } & Grewia damine Gaertn. & beriaa $(\mathrm{M})$ & $\mathrm{X}$ & & \\
\hline & Grewia schweinfurthii Burret & damage $(\mathrm{M})$, & $\mathrm{X}$ & & \\
\hline & Grewia villosa Willd. & bonkako (M) & $\mathrm{X}$ & & \\
\hline & Sterculia africana (Lour.) Fiori & kautsee (M) & $\mathrm{X}$ & & \\
\hline \multirow[t]{8}{*}{ Moraceae } & Ficus glumosa Delile & kuntsee $(\mathrm{M})$ & $\mathrm{X}$ & & \\
\hline & Ficus ingens (Miq.) Miq. & laze $(\mathrm{M})$ & $\mathrm{X}$ & & \\
\hline & Ficus platyphylla Delile & titee $(\mathrm{M})$ & $\mathrm{X}$ & & \\
\hline & Ficus sur Forssk. & semo $(M)$, sema $(A)$ & $\mathrm{X}$ & $\mathrm{X}$ & $X$ \\
\hline & Ficus sycomorus L. & bobi $(M)$, shafa $(A)$ & $\mathrm{X}$ & $\mathrm{X}$ & $\mathrm{X}$ \\
\hline & $\begin{array}{l}\text { Ficus sycomorus subsp. gnaphalocarpa (Miq.) } \\
\text { C.C.Berg }\end{array}$ & dawitchi $(M)$, tomiri $(A)$ & $\mathrm{X}$ & $\mathrm{X}$ & \\
\hline & Ficus vallis-choudae Delile & obori (M) & $\mathrm{X}$ & & \\
\hline & Ficus vasta Forssk. & shabi $(\mathrm{M})$, wompa $(\mathrm{A})$ & $\mathrm{X}$ & $X$ & \\
\hline Myrtaceae & Syzygium guineense (Willd.) DC. & ochi $(M)$, shiringi $(A)$ & $\mathrm{X}$ & $\mathrm{X}$ & \\
\hline \multirow[t]{2}{*}{ Olacaceae } & Ximenia americana L. & mukla $(A)$ & & $\mathrm{X}$ & \\
\hline & Ximenia caffra Sond. & mukalee (M) & $\mathrm{X}$ & & \\
\hline
\end{tabular}


Kidane et al. - Ethnobotany of Wild and Semi-Wild Edible Fruit Species used 471
by Maale and Ari Ethnic Communities in Southern Ethiopia

\begin{tabular}{|c|c|c|c|c|c|}
\hline Plant names & & & Stu & dy s & \\
\hline Scientific name & & Local names & $\begin{array}{l}\frac{\pi}{0} \\
\frac{\tilde{\sigma}}{\varrho} \\
\frac{0}{0} \\
\frac{\sigma}{\omega}\end{array}$ & 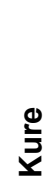 & 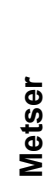 \\
\hline Phyllanthaceae & Bridelia micrantha (Hochst.) Baill. & aericho $(\mathrm{M})$ & $x$ & & \\
\hline Rhamnaceae & Ziziphus spina-christi (L.) Desf. & gaudii (M) & $\mathrm{x}$ & & \\
\hline Rosaceae & Rubus steudneri Schweinf. & sak "a" $(A)$ & & $\mathrm{X}$ & $\mathrm{X}$ \\
\hline & Rubus apetalus Poir. & sak "b" (A) & & $\mathrm{X}$ & $\mathrm{x}$ \\
\hline Rubiaceae & $\begin{array}{l}\text { Bullockia pseudosetiflora (Bridson) Razafim., } \\
\text { Lantz \& B.Bremer }\end{array}$ & meddale (M) & $x$ & & \\
\hline & Meyna tetraphylla (Schweinf. ex Hiern) Robyns & onakii (M) & $x$ & & \\
\hline & \begin{tabular}{|l} 
Vangueria apiculata K.Schum. \\
\end{tabular} & garo $(\mathrm{M})$ & $\mathrm{X}$ & & \\
\hline & Vangueria madagascariensis J.F.Gmel. & surangaro $(M)$, gara $(A)$ & $\mathrm{x}$ & $\mathrm{x}$ & \\
\hline & Mussaenda arcuata Poir. & murtsetse $(M)$, sertsegela $(A)$ & $\mathrm{X}$ & $x$ & \\
\hline & Psydrax schimperiana (A.Rich.) Bridson & gali $(\mathrm{M})$ & $\mathrm{x}$ & & \\
\hline Salicaceae & Flacourtia indica (Burm.f.) Merr. & gurchinchi $(\mathrm{M})$ & $x$ & & \\
\hline & Oncoba spinosa Forssk. & sewembulko $(M)$ & $\mathrm{x}$ & & \\
\hline Salvadoraceae & Dobera glabra (Forssk.) Juss. ex Poir. & bekee $(\mathrm{M})$ & $\mathrm{x}$ & & \\
\hline Sapotaceae & Manilkara butugi Chiov. & koshimi (A) & & $\mathrm{x}$ & $\mathrm{x}$ \\
\hline & Mimusops kummel Bruce ex A.DC. & gosho $(\mathrm{M})$ & $\mathrm{x}$ & & \\
\hline Zygophyllaceae & Balanites aegyptiaca (L.) Delile & donkey $(\mathrm{M})$ & $x$ & & \\
\hline & Balanites rotundifolia (Tiegh.) Blatt. & kuze (M) & $x$ & & \\
\hline
\end{tabular}


